\title{
Comparative Analysis of Haemagglutination Inhibition Antibody Production Against Three Lentogenic Newcastle Disease Virus Vaccines in Broiler Chicks
}

\author{
NC Shil ${ }^{1}$, M S Mahmud ${ }^{2}$, M M Amin $^{3}$ and M Anwar Hossain ${ }^{4 *}$ \\ ${ }^{I}$ Additional Veterinary Surgeon, FAO Technical Unit, Bird Flu Active Survillance Programme, Food and Agriculture Organization, Dhanmondi-R/A, \\ Dhaka-1205, Bangladesh, '2Department of Microbiology, Faculty of Heath Sciences, Gono Bishwabidyalay (University), Savar, Dhaka-1344, \\ Bangladesh, ${ }^{3}$ Department of Microbiology and Hygiene, Faculty of Veterinary Science, Bangladesh Agricultural University (BAU), Mymensingh-2202 \\ , Bangladesh, ${ }^{4}$ Department of Microbiology University of Dhaka, Dhaka 1000, Bangladesh
}

(Received 24 June, 2010; Accepted14 July 2011)

\begin{abstract}
The comparative analysis of haemagglutination Inhibitation (HI)-antibody production against three lentogenic Newcastle disease virus vaccines BCRDV (F-strain), Izovac $B_{1}$ Hitchner ${ }^{\circledR}$ (B $B_{1}$ strain) and Cevac New $L^{\circledR}$ (LaSota strain) was analyzed in broiler chicks. For this, three groups A, B and C, each consisted of 30 birds were vaccinated with single dosage at day 9 and the other group of 10 birds was maintained as unvaccinated control. Sera samples obtained randomly from 10 birds of each group on the day 17, 20, 28 and 32 and the HI titers estimated. Maternally derived antibody persisted to a maximum level of 17 day and than declined to minimum or none. The results revealed that vaccination of young birds with locally produced BCRDV by the Department of Livestock Service elevated HI antibody at comparable level with that of commercially available vaccine Izovac B1 Hitchner and Cevac New $L^{\circledR}$. The ' $F$ ' value preformed with mean $\pm S D$ of 17, 20, 28 and 32 days appeared non significant among the HI titers of the birds vaccinated with BCRDV, Izovac $B_{1}$ Hitchner ${ }^{\circledR}$ $\left(B_{1}\right.$ strain) and Cevac New $L^{\circledR}$.
\end{abstract}

Keywords: Maternally derived antibody (MDA); Newcastle disease (ND); Newcastle disease virus (NDV); Haemagglutination inhibition (HI); vaccines.

\section{Introduction}

Bangladesh is the world's most densely populated developing country with an area of about 1,47, 570 square kilometers. In the recent years, poultry become a growing and prospective industry in Bangladesh. Despite special emphasis given on this sector, the development of poultry industry is seriously threatened by the outbreaks of acute, contagious and fatal diseases. Newcastle disease (ND) also known as Ranikhet disease stands as a major problem towards the development of poultry in Bangladesh. It is caused by ssRNA containing Avulovirus -a newly formed genus under paramyxoviridae ${ }^{1-3}$. The factors that affect the disease may be host, species, age, immune status, infection with other organisms and environmental stress ${ }^{4-6}$. The disease is characterized by sudden appearance and rapid spread within the flock with high morbidity and mortality. It may cause $100 \%$ mortality in young chickens and $80-90 \%$ in adult chickens ${ }^{7-8}$.

Newcastle disease is endemic in Bangladesh with prevalence of viscerotropic velogenic strains ${ }^{8-9}$. The pathogenicity of velogenic NDV largely depends on F-protein cleavage site ${ }^{10}$. Proper biosecurity measure in farm and effective vaccination of flock are the only means to control the disease. Vaccination schedule against ND as followed by the Department of Livestock Services
(DLS) includes administration of live lentogenic vaccine termed as Baby Chick Ranikhet Dissease (BCRDV) of F-strain by intraocular inoculation in $1^{\text {st }}$ and $3^{\text {rd }}$ weeks old chicks followed by a live mesogenic vaccine termed as Ranikhet Disease Vaccine (RDV) of M-strain by intramuscular route at 10-12 weeks of age and are repeated in every six months interval. In Bangladesh, many farming do not follow this preventive measures, and thus, the disease appear every year in epidemic form which causes 40 $50 \%$ of the total mortality rate of poultry population in Bangladesh $^{8,11}$. However, the schedule of the vaccination differs with type of flocks, like broiler or layer, and (Newcastle Disease Virus) NDVs produced by local industry are not sufficient to meet the demand of poultry industry of Bangladesh. As a result, large quantities of live vaccines belonging to lentogenic and mesogenic strains are imported.

The preventive efficiency of a vaccine depends on its strict post and pre-manufacture quality control. In Bangladesh, the postquality control of ND vaccine is poorly maintained in some case particularly the modes and means of transport of vaccines under cold-chain system to end-users. This is the main reason of vaccination failure, which causes economic loss to the farmers. In most of the cases, these vaccines are found effective against

*Corresponding author:

M Anwar Hossain, Department of Microbiology, University of Dhaka, Dhaka 1000, Bangladesh, e-mail: anwar5533@yahoo.com, Tel: 880-2-9661920 73 ext. 7735/7730; Fax: $880-2-8615583$ 
$\mathrm{ND}$, however, a comparative study on $\mathrm{HI}$ antibody production in broiler, particularly with those produced by the DLS and other commercially available vaccine (CAV) manufacturers are important. Furthermore, there is no prerequisite or compulsion of such data for the imported ND vaccines especially in regard to the influence of environment that is prevailing in Bangladesh. In consideration of these factors, this study was undertaken to observe the persistence of maternally derived antibody (MDA) to NDV in chickens and to evaluate antibody production following single vaccination with BCRDV, Izovac $B_{1}$ Hitchner ${ }^{\circledR}$ and Cevac New $\mathrm{L}^{\circledR}$ in broiler chicks and also to compare the efficiency of BCRDV with those of two commercial ND vaccines i.e. Izovac $\mathrm{B}_{1}$ Hitchner ${ }^{\circledR}$ and Cevac New L ${ }^{\circledR}$.

Prior to vaccination, blood samples were collected from broilers to measure maternal antibody on day 1 and 9 . Three groups of A, $\mathrm{B}$ and $\mathrm{C}$, each consisted of 30 birds were vaccinated with single dosage at day 9 and another group of 10 birds maintained as unvaccinated control. Elevation of HI titers indicated immune response in chickens after intraocular route (eye-drop) vaccination. MDA persistently maintained in vaccinated broiler chickens up to 20 days old and then decline to minimum or none (Table-1). Moreover, in control group D, high level of HI titers were found during first two weeks of life which correlated the findings reported elsewhere $8,9,12,13$. Balla ${ }^{14}$ reported higher levels of MDA maintained up to 12-15 days old chickens and then decline to minimum. Saeed et al. ${ }^{17}$ reported that MDA decline to zero at day 25. The immune response is improved in elder chicks as levels of MDA fall and immunological maturity develop ${ }^{16}$.

Table 1. Persistence of maternally derived antibody (MDA) HI titer of the control chicks

\begin{tabular}{lcc}
\hline Bird age & \multicolumn{2}{c}{ Control MDA Antibody titers } \\
& Average range of HI titers & Mean \pm SD \\
\hline Day 1 & $64-128$ & $108.80 \pm 30.91$ \\
Day 9 & $16-32$ & $32.00 \pm 13.06$ \\
Day 17 & $8-16$ & $10.40 \pm 3.86$ \\
Day 20 & $4-8$ & $5.20 \pm 1.93$ \\
Day 28 & $2-4$ & $3.40 \pm 0.97$ \\
Day 32 & $2-4$ & $2.60 \pm 0.97$ \\
\hline
\end{tabular}

The objectives of this study was to address a comparative performance of BCRDV with those of two CAV such as Izovac $\mathrm{B}_{1}$ Hitchner ${ }^{\circledR}\left(\mathrm{B}_{1}\right.$ strain) and Cevac New L ${ }^{\circledR}$ (LaSota strain) in chicks. For this, birds of the three groups such as $\mathrm{A}, \mathrm{B}$ and $\mathrm{C}$ were vaccinated with $B C R D V$, Izovac $B_{1}$ Hitchner ${ }^{\circledR}\left(B_{1}\right.$ strain $)$ and Cevac New L ${ }^{\circledR}$ (LaSota strain) respectively, and 10 sera samples obtained randomly from each group on day 17, 20, 28 and 32 and $\mathrm{HI}$ titers was estimated. A comparative picture is illustrated in Table 2 and revealed that the HI titers of BCRDV on the 17 day were $108.80 \pm 30.91$ while that of Izovac $B_{1}$ Hitchner $^{\circledR}$ and Cevac New $L^{\circledR}$ were $121.60 \pm 56.04$ and $172.80 \pm 74.21$ respectively. Similar higher HI titer was observed for 20 and 28 days old birds in case of Cevac New $L^{\circledR}$ vaccinated group, whereas, the value declined to same level on the 32 days in all the three cases (Table-2).

In this context, the utility of measurement of HI antibodies of sera to qualify the protection capacity of birds from an infection with NDV needs to be mentioned. Lancaster ${ }^{5}$ reported that serological response of chickens to NDV either from natural infection or vaccination is manifested by the appearance of both HI and VN (Virus neutralization) antibodies. Hossain (1989) $)^{17}$ and Haplin $(1978)^{18}$, stated that $\mathrm{HI}$ and $\mathrm{VN}$ antibodies production follow a similar course, but $\mathrm{VN}$ antibody persist longer and in relatively higher titers. It should further be mentioned that HI test provides a measurement of the ability of serum from an exposed birds to inhibit agglutination of chick RBC by NDV, where as $\mathrm{VN}$ or $\mathrm{SN}$ indicates the ability of serum to neutralize infective property of NDV, and therefore provides more precise information about protection. However, as regards vaccination of chicks against NDV in earlier days using of lentogenic strains is recommended. Vaccination with LaSota strain causes considerably greater problems in young susceptible birds than Hitchner ${ }^{\circledR} \mathrm{B}_{1}$ strain, although LaSota induces a stronger immune response $^{19}$. In conclusion, vaccination of young birds with BCRDV produced by DLS shows elevated HI antibody at comparable level with that of commercially available vaccine Izovac B1 Hitchner and Cevac New $L^{\circledR}$, though Cevac New $L^{\circledR}$ produced the highest level of antibody among the three.

Table 2. HI titer of groups $A, B, C$ and $D$ birds

\begin{tabular}{|c|c|c|c|c|c|c|c|c|}
\hline \multirow[t]{2}{*}{ Name of vaccine } & \multicolumn{2}{|c|}{17 days birds } & \multicolumn{2}{|c|}{20 days birds } & \multicolumn{2}{|c|}{28 days birds } & \multicolumn{2}{|c|}{32 days birds } \\
\hline & Range & Mean \pm SD & Range & Mean \pm SD & Range & Mean \pm SD & Range & Mean \pm SD \\
\hline BCRDV (Group A) & $64-128$ & $108.80 \pm 30.91$ & $32-64$ & $44.80 \pm 16.52$ & $16-32$ & $20.80 \pm 7.73$ & $8-16$ & $11.20 \pm 4.13$ \\
\hline $\begin{array}{l}\text { Cevac New } L^{\circledR} \\
\text { (Group C) }\end{array}$ & $64-256$ & $172.80 \pm 74.21$ & $32-128$ & $73.60 \pm 30.36$ & $16-64$ & $30.40 \pm 14.01$ & $8-16$ & $12.80 \pm 4.13$ \\
\hline $\begin{array}{l}\text { Unvaccinated control } \\
\text { (Group D) }\end{array}$ & $8-16$ & $10.40 \pm 3.86$ & $4-8$ & $5.20 \pm 1.93$ & $2-4$ & $3.40 \pm 0.97$ & $2-4$ & $2.60 \pm 0.97$ \\
\hline $\begin{array}{l}\text { Level of Significance } \\
\text { (F value) }\end{array}$ & & NS (19.167) & & NS (23.093) & & NS (17.044) & NS (17.044) & \\
\hline
\end{tabular}

$\mathrm{SD}=$ Standard deviation; $\mathrm{HI}=$ Haemagglutination inhibition; $\mathrm{NS}=$ Non-significant 


\section{References}

1. De Leeuw Q and Peeters B. 1999. Complete nucleotide sequence of NDV. Evidence for the existence of a new genus within the subfamily Paramyxovirinae. J Gen Virol. 80: 131-136.

2. Chang PC, Hsieh ML, Shien JH, Graham DA, Lee MS and Shieh HK. 2001. Complete nucleotide sequence of avian paramyxovirus type 6 isolated from ducks. J Gen Virol. 82: 2157-2168.

3. Mayo MA. 2002. A Summery of Taxonomic changes recently approved by ICTV. Arch.Virol. 147: 1655-1656.

4. Cheville NF, Stone H, Riley J and Ritchie AE. 1972. Pathogenesis of virulent Newcastle disease in Chickens. J Am Vet Med Assoc. 161: 161-179.

5. Lancaster JE. 1981. Newcastle disease. In: Gibba. E.P.J. (Ed), Virus Disease of Food Animals, Vol. 1, Disease monograph, Academic press, New York, pp. 433-465.

6. Campbell RSF.1986. The pathogenesis and pathology of avian respiratory infection. Vet But. 56: 521-543.

7. Brandly CA .1950. Newcastle disease, Am J Vet Med Assoc. 116: 139.

8. Chowdhury SI, Chowdhury TIMFR, Sarker AJ, Amin MM and Hossain WIMA. 1982. Studies on Newcastle disease in Bangladesh. A research report: The role of residual maternal antibody on immune response and selection of an optimum age for primary vaccination of chicks. pp. 12-22.

9. Islam MR, Huque QME, Giasuddin MJ and Rahman MM. 2003. Assessment of Maternally derived antibody of commercial flock against Newcastle disease. Proceedings $3^{\text {rd }}$ International poultry show and seminar, Bangladesh China Friendship Conference Center, Dhaka, Bangladesh $28^{\text {th }}$ February-2 ${ }^{\text {nd }}$ March 2003.
10. Lin MY, Liu HJ and Ke GM. 2003. Genetic and antigenic analysis of Newcastle diseases viruses from recent outbreaks in Taiwan. Avian Pathol. 32: 345-350.

11. Talha AFSM, Hossain MM, Chowdhury EH, Bari ASM, Islam MR and Das PM. 2001. Poultry diseases occurring in Mymensingh district of Bangladesh. The Bangladesh Vet. 18: 20-23.

12. Ibrahim AL, Lai MC and Aini I.1982. Spray vaccination with an improved F Newcastle disease vaccine: A comparison of efficacy with the $\mathrm{B}^{1}$ and LaSota vaccines. British Vet J. 139: 213-219.

13. Westbury HA. 1984. The serological responses of chickens to mass vaccination with a live $\mathrm{V}_{4}$ NDV vaccine in the field and in the laboratory meat chickens. Aust Vet J. 68: 85-89.

14. Balla L. 1986. Use of standardized HI test for monitoring immunity to Newcastle Disease. I. Experiments to standardize the HI test II. Antibody response after different immunization schedules. Mayar Allatorvoso Lapja. 41(2): 98-109.

15. Saeed Z, Ahmad S, Rizvi, AR and Ajmal, M. 1988. Role of maternal antibody in determination of an effective Newcastle disease vaccination programme. Pak J Vet Res. 1: 18-21.

16. Paulillo AC. Montassier HJ, Berchieri-Junior A, Ariki J, Richtzenhain LJ. Nakaghi LSO, Barbosa JC and Quintana, JL. 1987. Newcastle disease. IV. Experimental assay of different vaccination routes with the LaSota strain in broilers. Ars Veter. 3(1): 73-79.

17. Hossain SM, Amin MM, Hossain WIMA and Sarker AJ. 1989. Stability of virus titre of Newcastle disease vaccines prepared in Bagladesh. Bangladesh Vet J. 23(1-4): 25-33.

18. Haplin B. 1978. Patterns of Animal disease. In: Immunity and Epidemiology. The English Language Book Society and Bailliere Tindal. London. pp. 151-157.

19. OIE Manual. 2000. Manual of Standards for Diagnostics tests and Vaccines. $4^{\text {th }}$ ed. pp. $189-207$. 